\title{
11. EARLY CRETACEOUS CALCAREOUS ALGAE OF THE NORTHWEST PACIFIC GUYOTS ${ }^{1}$
}

\author{
Jean-Pierre Masse $^{2}$ and Annie Arnaud Vanneau ${ }^{3}$
}

\begin{abstract}
We describe 10 genera and 11 species of dasycladale algae, 2 genera and 2 species of Rhodophyta, and 2 genera of uncertain affinities from carbonate platform sequences drilled at Ocean Drilling Program Sites 878 and 879 on the MIT and Takuyo-Daisan guyots, respectively (northwest Pacific). Early Aptian and Albian assemblages contain distinct species associations with Mediterranean affinities, and some American forms are also recorded.
\end{abstract}

\section{INTRODUCTION}

Published records of Early Cretaceous calcareous algae in the Pacific regions are few and mainly based on dredge material. The richest associations containing representatives of Chlorophyta (Udoteaceae, Dasycladaceae) and Rhodophyta (Peyssonneliaceae, Corallinaceae, Gymnocodiaceae, Solenoporaceae) were described from the Japanese Seamounts (Konishi, 1987; Pascal, 1986; Grötsch and Flügel, 1992), whereas the Mid-Pacific Mountains yielded Rhodophyta (Hamilton, 1956; Grötsch and Flügel, 1992). This material was considered to be Aptian-Albian in age.

During Ocean Drilling Program (ODP) Leg 144, five guyots were drilled to investigate the evolutionary development of carbonate platforms associated with Cretaceous volcanic edifices. In two localities-MIT and Takuyo-Daisan guyots (Seiko cluster, Japanese Seamounts), corresponding to Sites 878 and 879 , respectively-Early Cretaceous platform carbonates were cored (Premoli Silva, Haggerty, Rack, et al., 1993) and yielded calcareous algae (Fig. 1).

The following descriptions are based on analyses of the available collection of thin sections provided on board plus additional thin sections subsequently processed on core material after the cruise.

A study of calcareous algae from Sites 878 and 879 provides an opportunity to illustrate the Aptian-Albian interval, including the lower Aptian, which has been poorly documented in the Pacific. This analysis also permits a regional test for the stratigraphic range of some taxa relatively to other organisms (mainly foraminifers), as well as chemo- and magnetostratigraphic data, and a comparison of the corresponding range to the Mediterranean, where extensive studies on the group have been performed during the two last decades. In this chronostratigraphic framework, paleobiogeographic and paleoecologic considerations are achieved.

\section{STRATIGRAPHY}

Lithostratigraphic and biostratigraphic data (Fig. 2) are given after Premoli Silva, Haggerty, Rack, et al. (1993) with some revisions.

\section{MIT Guyot (Site 878)}

The platform carbonates correspond to the following units:

\footnotetext{
'Haggerty, J.A., Premoli Silva, I., Rack, F., and McNutt, M.K. (Eds.), 1995. Proc. ODP, Sci. Results, 144: College Station, TX (Ocean Drilling Program).

${ }^{2}$ Centre de Sédimentologie \& Paléontologie, URA 1208 du CNRS, Université de Provence, 3 Place Victor Hugo, 13331 Marseille, Cedex 3 France.

${ }^{3}$ Institut Dolomieu, Université de Grenoble, I Rue M. Gignoux, 38031 Grenoble, Cedex France.
}

Unit II (3.2-236 mbsf): white gastropod-rich wackestone, packstone, and mudstone; peloidal packstone with fenestral fabric; peloidalgal wackestone and minor grainstone to rudstone (upper Albian);

Unit III (236-399.7 mbsf): grainstone and subordinate muddy limestones (middle-upper Albian);

Unit IV (399.7-604.3 mbsf): polymictic breccia with basalt and limestone clasts in a grayish-green matrix (upper Aptian);

Unit V (604.3-722.5 mbsf): skeletal grainstone packstone and wackestone with nerineids, oysters, and corals (lower Aptian); this unit overlies the volcanic basement of MIT Guyot.

\section{Takuyo-Daisan Guyot (Site 879)}

The platform carbonates correspond to Unit I (0-169.7 mbsf), with the following subdivisions:

Subunit IA ( $0-44.3 \mathrm{mbsf})$ : coral-mollusk rudstone and floatstone with skeletal grainstone and packstone matrix; the basal part consists of an oncolite-rich interval;

Subunit IB (44.3-140.8 mbsf): poorly recovered skeletal packstone and wackestone with rare grainstone;

Subunits IC, ID, and IE (140.8-169.7 mbsf): transitional (containing mixed carbonate and volcanic or clay-sandy material) between the carbonate system and its volcanic and volcanic/sedimentary basement; the carbonate succession is ascribed to the upper Aptian-Albian.

\section{SYSTEMATIC PALEONTOLOGY}

Explanations for the abbreviations used in the following descriptions can be found in Table 1 .

\section{Chlorophyta \\ Dasycladales}

\begin{abstract}
Genus Acroporella Praturlon, 1964 emend. Praturlon and Radoicic, 1974 Acroporella radoiciciae Praturlon
\end{abstract}

(PI. 1, Figs. 1-2)

The genus is characterized by a nonsegmented cylindrical thallus with alternating verticils of primary cylindrical ramifications oblique to the main axis, followed by short buttonlike secondaries that form a subcontinuous cortex (Praturlon and Radoicic, 1974).

Two sections were recorded from Samples 144-878A-46M-3, 123-125 $\mathrm{cm}$, and $-45 \mathrm{M}-3,123-125 \mathrm{~cm}$.

The obliquity of the ramifications to the main axis are well expressed, but secondaries have not been observed, a situation often found in specimens where micritization of the organic part of the thallus has been active (e.g., Praturlon, 1964; Luperto-Sinni and Masse, 1984). The dimensions ( $D=0.6$ 


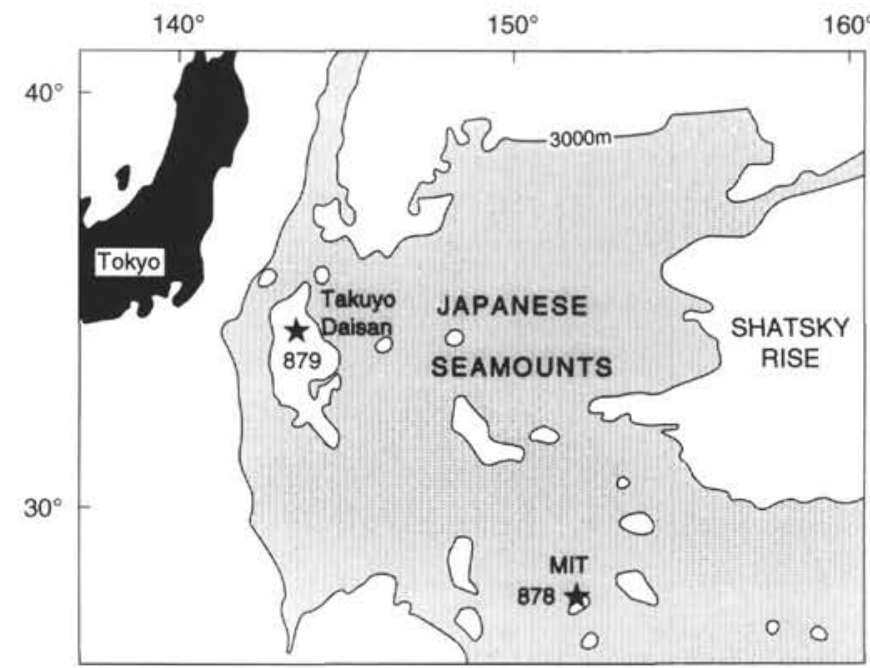

Figure 1. Location of MIT (Site 878) and Takuyo-Daisan (Site 879) guyots in the northwest Pacific.

$\mathrm{mm}, \mathrm{d}=0.18-0.20 \mathrm{~mm}$, and $\mathrm{h}=0.10 \mathrm{~mm}$ ) conform to those of the type material from Italy,

This species is known from the Barremian-early Aptian interval in Mediterranean regions (Praturlon and Radoicic, 1974; Masse, 1976; Luperto-Sinni and Masse, 1984).

Genus Cylindroporella Johnson, 1954

Cylindroporella $\mathrm{cf}$. barnesii Johnson

(PI. 1, Fig. 3)

Sample 144-878A-2R-1, 3-4 cm, provided two longitudinal, slightly oblique sections that possess an unperforated axial tube flanked by poorly preserved (i.e., micritized) remnants of fertile ampulae. The diagnostic features of the genus Cylindroporella (that is to say, the alternate sterile and fertile ramifications within single whorls that are not visible) are alike in many specimens of Cylindroporella barnesii that have previously been mentioned (e.g., Conrad, 1982; Kuss and Conrad, 1991). The specimens recorded here closely resemble that species, especially considering the dimensions ( $D=0.30 \mathrm{~mm}, \mathrm{~d}=0.08$ $\mathrm{mm}$, and $\mathrm{ds}=0.08 \mathrm{~mm}$ ) and the gross habit. They are also comparable to Cylindroporella bradarici Sokac, which shows a strong affinity with Cylindroporella barnesii (Sokac, 1990).

Cylindroporella barnesii was described from the Albian of Texas (Johnson, 1954). A close or identical form has also been reported from the Sinai at the same level (Kuss and Conrad, 1991). The type level for Cylindroporella bradarici in the Dinarides is also dated as Albian. As pointed out by Bassoullet et al. (1978), the majority of pre-Albian occurrences of C. barnesii are taxonomically poorly constrained; moreover, many forms ascribed to that species in the upper Aptian-Albian belong to other taxa (e.g., Cylindroporella barnesii, figured by Saint-Marc [1970] from Lebanon, which pertains to Montiella).

\author{
Genus Montiella Morellet and Morellet 1922 \\ emend. Genot, 1987 \\ Montiella elitzae (Bakalova) \\ (Pl. 1, Figs. 4-5)
}

Formerly ascribed to Cylindroporella by Bakalova (1971), this taxa was transferred to Montiella Morellet by Radoicic (1980). This generic attribution was based on the arrangement of the second-order fertile blister relative to the peduncle (bearing the fertile blister), which branches from near the base of the primary ramifications; that is, fertile and sterile ramifications are not independent as in Cylindroporella Johnson but originate from a single split ramification. This interpretation was rejected by Bucur (1993) after a reevaluation of the characters of Montiella munieri Morellet and Morellet (type species of the genus), the weakly calcified axial tube of which does not allow one to observe the connection between the peduncle of the blister and the sterile ramification. Although Genot (1987) considered the Tertiary taxa with the two ramifications actually connecting, Montiella is accepted here for the Cretaceous forms possessing this disposition.

Montiella elitzae is represented in Sample 144-878A-51R-2, 5-9 cm, by two sections: a longitudinal oblique tangential and a tangential. The longitu-

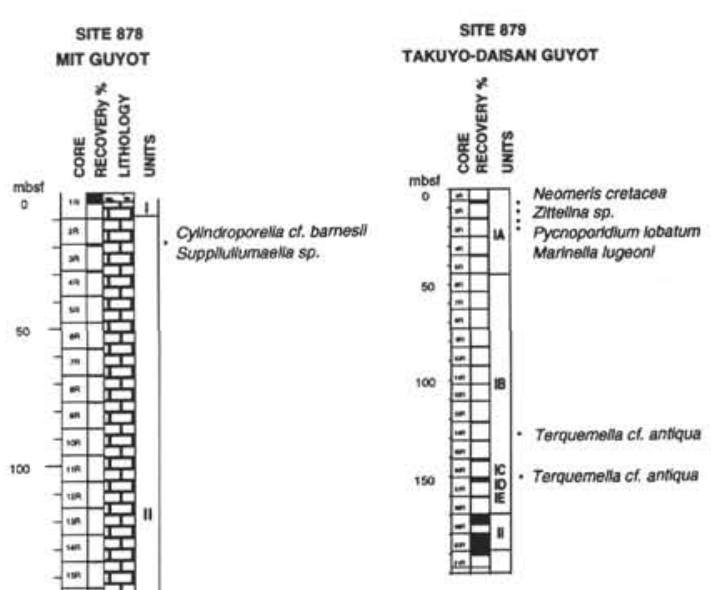

- Polystrata alba

Polystrata alba

Boueina sp.

Polystrata aloa

300

- Polystrata aiba

- Parachaetetes asvapati

- Poystrata alba

- Triploporella aff. steinmanni

- Polystrata alba

- Polystrata alba

Acroporella radoiciciae

- Acroporella radoiciciae

450

Montiella entzae

Polystrata albe

Satpingoporeilla cf. melitae

100

.

-

$\infty$

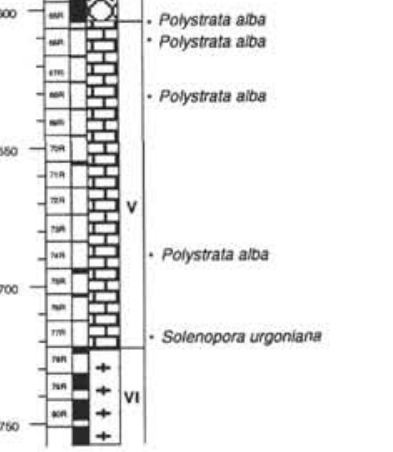

- Salpingoporetlia ct. muenibergil

Figure 2. Stratigraphy of the MIT and Takuyo-Daisan sequences, with the position of the calcareous algae occurrences. 
dinal section displays the imbrication of the fertile blisters and the distal part of the adjacent "basal" ramification. (In Cylindroporella, this sterile branch is located in the central part of the space left by four adjacent fertile ampullae.) The attachment of the blister to the peduncle was not observed, but the transverse section displays the significant subpolygonal, more or less concave shape of the secondaries. The dimensions $(\mathrm{D}=1.1 \mathrm{~mm}, \mathrm{~d}=0.16 \mathrm{~mm}$, and $\mathrm{ps}$ $=0.28 \mathrm{~mm}$ ) fit with those given by Bucur (1993) for material from the Barremian-early Aptian age of the Resita-Moldova (western Romania). The species is known from the Hauterivian to the Albian in the Mediterranean area (Bakalova, 1971; Granier, 1986; Conrad and Masse, 1989). Two closely related species, even identical-Montiella benizarensis (Fourcade et al.) (Granier, 1991) and Montiella barbui (Dragastan) (Dragastan, 1978)-are documented from the same regions and possess the same biostratigraphic range.

Genus Neomeris Lamouroux, 1816 emend. Deloffre, 1970

Neomeris cretacea Steinmann 1899

$$
\text { (Pl. 1, Figs. 6-8) }
$$

This species, first described by Steinmann (1899) from Mexico, is frequently mentioned in the literature dealing with Early Cretaceous algae, from the Hauterivian to the Albian (Bassoullet et al., 1978). The revision of the type material recently performed by Barattolo (1990b) shows that the diagnostic characters of Neomeris cretacea Steinmann were poorly documented in most of recorded Early Cretaceous Neomeris, the actual specific position of which frequently remains questionable. Consequently, the wide geographic and stratigraphic distribution of this species is presently uncertain.

Almost 20 sections of Neomeris were recorded in Sections 144-879A-1 R-1 and $-2 \mathrm{R}-1$, all from transverse or transverse-oblique fragments. All show the typical Neomeris arrangement: a pedunculate ellipsoidal ampulla surrounded by two sterile ramifications. The peduncle and the steriles are assumed to originate from a single primary, the calcification of which is poor or absent.

Because sections of the whole thallus are lacking, the dimensions of the outer and inner parts of the calcareous sheath are difficult to measure. From the apparent curvature of the available fragments, D is tentatively $2 \mathrm{~mm}$. The dimensions of the ampullae (length $=0.12-0.20 \mathrm{~mm}$, width $=0.8-0.10 \mathrm{~mm}$ ) and the thickness of the calcified sheath $(0.25-0.30 \mathrm{~mm})$ are similar to those from Neomeris cretacea. In spite of the lack of any tangential section allowing the observation of the ampullae/sterile network (the geometry of which is highly significant for systematic identification), the specimens recorded here are ascribed to the Mexican species.

In its type locality, Neomeris cretacea was found in beds of Albian age, probably middle Albian (Barattolo, 1990b).

Genus Salpingoporella Pia, in Trauth, 1918

Salpingoporella cf. muehlbergii (Lorenz)

$$
\text { (Pl. 1, Fig. 9) }
$$

Sample 144-878A-61R-2, 75-78 cm, provided a longitudinal section conforming to the genus Salpingoporella: cylindrical thallus with simple verticillate ramifications, the preservation of which is nevertheless very poor. The systematic position of this form is mainly based, therefore, on the relative dimensions of the external and internal diameters $(D=0.24 \mathrm{~mm}$ and $\mathrm{d}=0.14$ $\mathrm{mm}$ ). These quantitative data conform to those of the minute specimens of Salpingoporella muehlbergii revised by Conrad (in Bassoullet et al., 1978). In this respect, they are close to Salpingoporella carpathica Dragastan, a probable junior synonym Salpingoporella muehlbergii according to Conrad (1970). Its stratigraphic distribution is from the uppermost Hauterivian to the lower Aptian (Bassoullet et al., 1978; Conrad and Masse, 1989).

\section{Salpingoporella cf. melitae Radoicic}

$$
\text { (PI. 1, Fig. 10) }
$$

Salpingoporella melitae belongs to the group of species with funnelshaped ramifications perpendicular to the main axis, that is, to the same group as Salpingoporella muehlbergii (see above).

Sample 144-878A-55R-3, 46-49 cm, yielded a poorly preserved transverse section showing the verticillate ramifications with distal abrupt widening, a pattern well expressed in Salpingoporella melitae. The dimensions $(\mathrm{D}=0.35$ $\mathrm{mm}, \mathrm{d}=0.16 \mathrm{~mm}, \mathrm{w}=$ about $18-20$ ), are close to those from small or juvenile specimens from the above-mentioned species described by Radoicic (1965).

This species ranges from the Hauterivian to the lower Aptian (Bassoullet et al., 1978; Conrad and Masse, 1989).
Table 1. Abbreviations used for dasyclad nomenclature.

\begin{tabular}{cl}
\hline Abbreviation & \multicolumn{1}{c}{ Description } \\
\hline D & Outer diameter in transverse section \\
d & Inner diameter in transverse section \\
w & Number of ramifications per whorl \\
ps & Diameter of the secondary ramifications \\
e & Thickness of the calcareous sheath \\
h & Distance between two adjacent whorls \\
ds & Diameter of the fertile ampulla
\end{tabular}

Genus Similiclypeina Bucur, 1993

Similiclypeina somalica (Conrad et al., 1983)

(Pl. 1, Fig. 11)

This taxa, formerly ascribed to Clypeina (Conrad et al., 1983), is now placed in the genus Similiclypeina created by Bucur (1993). With Clypeina, the whorls (i.e., fertile whorls) are clearly independent and separated from each other by the tubular axial portion bearing sterile ramifications (e.g., see Radoicic, 1969). In Similiclypeina, the consecutive alternating whorls are in contact but not imbricated and sterile ramifications are lacking. Furthermore, the ramifications show a proximal inflation connected to the axial hollow by a fine pore. These geometric attributes and the elongated, tubular, outwardthinning shape of the branches depart from those of Holosporella, a genus to which Granier (1992) referred the former "Clypeina" somalica.

An oblique, longitudinal section from Sample 144-878A-45M-3, 123-125 $\mathrm{cm}$, shows the proximal inflation and wide spacing (both longitudinally and transversally) of the ramifications, slightly oblique to the central axis. The thallus dimensions $(D=0.54 \mathrm{~mm}, \mathrm{~d}=0.26 \mathrm{~mm}$ ) are very close to those from the type material of Somalia.

Similiclypeina somalica, originally described from the upper Barremianlower Aptian from Somalia and southern Italy (Conrad et al., 1983), is also present at the same level in Israel (see Johnson, 1968b, pl. 7, fig. 4). A closely related, or even identical, form was mentioned from the upper Barremian of the Resita-Moldova region in western Rumania (Bucur, 1993).

\section{Genus Suppiluliumaella Elliott, 1968}

The genus established by Elliott (1968) for Suppiluliumaella polyreme is characterized by verticils of ramifications showing a thin, inclined, proximal peduncle with a terminal swelling bearing small, short secondaries. Montenegrella Sokac and Nikler proposed in 1973 is considered by Barattolo (1983) to be a junior synonym of Suppiluliumaella, a point of view accepted here.

\section{Suppiluliumaella sp. \\ (Pl. 2, Fig. 1)}

An oblique longitudinal section was found in Sample 144-879A-2R-1, $132-138 \mathrm{~cm}$. The ramifications show a thin inclined peduncle and a distal ampulla. The cortical portion is densely micritized; therefore, the secondaries (here hypothesized) are not preserved. The ramifications clearly alternate for two adjacent verticils. The peduncle is set at an angle of near $30^{\circ}$ from the vertical axis, then turns to about $45^{\circ}$ in the distal part, bearing the ampulla, the diameter of which is $0.10 \mathrm{~mm}$.

The geometry of the ampulla and its mode of attachment to the peduncle depart from those of Suppiluliumaella tubifera (Sokac and Nikler) (pro-Montenegrella) (Sokac and Nikler, 1973), Suppiluliumaella alimani (Dragastan) (Dragastan, 1989), and Suppiluliumaella gocanini Radoicic (Radoicic, 1972). In Suppiluliumaella schroederi Barattolo, forms with similar dimensions ("group with medium size" in Barattolo, 1983) display ramifications with a wider distal ampulla, the section of which is polygonal and subrectangular.

The Pacific form, therefore, closely resembles Suppiluliumaella polyreme Elliott and Suppiluliumaella erikfluegeli Dragastan. Nevertheless, the high degree of micritization and the difficulty in observing the secondaries do not allow an unambiguous specific identification.

Suppiluliumaella is mainly documented from the Valanginian(?)Cenomanian interval (Granier and Deloffre, 1993). Jurassic forms ascribed to that genus (Dragastan, 1989) are poorly defined.

\section{Genus Terquemella Munier-Chalmas, 1877}

Terquemella is a taxon form used for spherical calcareous bodies with globular pores, interpreted as cyst cavities. Terquemella is ascribed to a repro- 
ductive organ of a Dasycladale, the systematic position of which is unknown (Munier-Chalmas, 1877).

\section{Terquemella cf. antiqua (Pia)}

$$
\text { (Pl. 2, Fig. 2) }
$$

Samples 144-879A-16R-1, 95-99 cm, and -14R-1, 8-13 cm, provided numerous sections of a form very close to Terquemella antiqua (Pia), a taxon formerly ascribed to the genus Acicularia (Pia, 1936) and here ascribed to Terquemella because of its spherical shape. The external diameter $(0.12-0.16$ $\mathrm{mm})$ and the size of the cysts $(0.02-0.03 \mathrm{~mm})$ are slightly lower than those of Pia's specimens; the number of cysts $(7-10)$ is similar.

Terquemella antiqua is known from the Cenomanian-Turonian of Libya (Pia, 1936); closely related forms have been mentioned from the Albian of Somalia (Prestat, 1977), Texas (Johnson, 1968a), and Lebanon (SaintMarc, 1970).

\section{Genus Triploporella Steinmann 1880 emend. Triploporella aff. steinmannii Barattolo} (Pl. 2, Fig. 3)

The Cretaceous representatives of Triploporella have been carefully analyzed by Barattolo $(1980,1981,1982 \mathrm{a}, 1982 \mathrm{~b}, 1983)$, with some additional inputs from Bucur (1993). The genus is characterized by tight primaries (fertile), ending in calcified or noncalcified secondaries. The primaries are attached to the main axis (i.e., they lack a peduncle). Cyst containers are frequently calcified, a criterion used for specific identification. An oblique section of a thallus wall was recorded in Sample 144-878A-37M-2, $32-35 \mathrm{~cm}$. Primary ramifications are fairly calcified and display cyst containers, the internal characters of which are poorly preserved. The secondary ramifications were not clearly observed; whether they were not calcified or have been subsequently altered by micritization remains an open question. The occurrence of calcified cyst containers shows that this species belongs to the group of T. praturlonii Barattolo, T. decastroi Barattolo, T. steinmannii Barattolo, T. matesina Barattolo, $T$. duplicata (Sokac and Nikler), and $T$. carpatica Bucur. The calcification of the primaries is thin $(0.02 \mathrm{~mm})$ and continuous from the main axis toward the external margin; two aspects not known in T. matesina and $T$. decastroi, however, do possess calcified secondaries. The diameter of the primaries (near $0.20 \mathrm{~mm}$ ) is in the range of the smaller recorded sizes from the former species ( $T$. steinmannii) and is close to those from $T$. carpatica, which shows a poorly calcified middle part of the calcareous sheath. Consequently, the Pacific form is close to T. steinmannii, which has very limited calcified secondaries and irregularly arranged cyst containers (in the other species, they tend to parallel the axis of the primaries): The diameter of the cyst containers, with an ellipsoid shape, is between 0.06 and $0.08 \mathrm{~mm}$, which is smaller than those from the sample of $T$. steinmannii provided by Barattolo (1983). T. steinmannii is only known from its Mexican-type locality near Orizaba (Veracruz); the age of the corresponding beds is considered as Albian (probably middle Albian) (Barattolo, 1983).

$$
\begin{gathered}
\text { Genus Zittelina Morellet and Morellet, } 1913 \\
\text { emend. Barattolo, } 1985 \\
\text { Zittelina sp. } \\
\text { (Pl. 2, Figs. 4-5) }
\end{gathered}
$$

One oblique, longitudinal section was found in Sample 144-879A-2R-1, $0-4 \mathrm{~cm}$, showing the following characteristics:

1. A large-sized thallus $(\mathrm{L}=3.8 \mathrm{~mm}, \mathrm{D}=2.1 \mathrm{~mm})$;

2. Calcification of the calcareous sheath restricted to the proximal and distal ends of the ramifications, with the median part corresponding to attached rows of "free" cyst containers, parallel to the axis of the ramifications;

3. A lack of secondaries;

4. An ellipsoidal shape to the cyst containers.

These attributes are diagnostic for the genus Zittelina Morellet and Morellet emended by Barattolo (1985).

The inner diameter is relatively narrow $(\mathrm{d}=0.6 \mathrm{~mm})$, and the ramification network (seen in the transverse section relative to the axis of the ramification) delineated by the cyst containers is irregular. The dimensions of the cyst containers are $0.08 \mathrm{~mm}$ (short axis of the ellipsoid) and $0.12 \mathrm{~mm}$ (long axis of the ellipsoid). The diameter of the ramifications is about $0.20 \mathrm{~mm}$. Because this form is only known by a single specimen, the above-mentioned quantitative parameters are to be regarded as poorly significant on a taxonomic point of view. The genus is currently represented by seven species: six have been described from the Paleocene and the Eocene, and one from the Early Creta- ceous (Barattolo, 1985; Masse et al., 1993). Among those, only two possess a calcified proximal portion adjacent to the main axis, like the species recorded here: Z praturlonii (Barattolo and De Castro) and Z. hispanica Masse et al. (1992). Z. praturlonii has no cortical calcification. Therefore, Z. hispanica (Hauterivian) is the closest species, but its dimensions are far larger and the $\mathrm{D} / \mathrm{d}$ ratio is significantly lower (1.6 instead of 3.5 ) than those for the Pacific form. This form is considered a new species; nevertheless, the description needs additional specimens.

\section{Caulerpales}

\author{
Genus Boueina Toula, 1884 \\ Boueina sp. \\ (PI. 3, Fig. 1)
}

This genus, which is characterized by coarse tubular threads with several orders of ramifications outward, forming a dense filamentous cortical zone (i.e., the diameter of the tubes narrows after each branching), is represented by a single specimen in Sample 144-878 A-30M-1, 29-31 cm. The corresponding section displays the cortical part with its multiple branching filaments. The absence of a cross section showing both the medullar and cortical zones prevented a specific identification.

\section{Rhodophyta \\ Peyssonneliaceae \\ Genus Polystrata Heydrich, 1905 \\ Polystrata alba (Pfender)}

(Pl. 3, Figs. 2-3)

Polystrata alba is an encrusting red alga with yellow-brown cell walls and curved cellular rows with synaptic openings; the corresponding pattern is mainly tubular. Formerly ascribed to Pseudolithothamnium by Pfender (1936), then transferred to Ethelia by Massieux and Denizot (1964), this form is currently placed in the genus Polystrata (Denizot, 1968).

Sections of crusty fragments have been recorded in Samples 144-878A$42 \mathrm{M}-2,89-93 \mathrm{~cm} ;-65 \mathrm{R}-6,35-37 \mathrm{~cm} ;-68 \mathrm{R}-1,11-16 \mathrm{~cm} ;-26 \mathrm{M}-1,22-25 \mathrm{~cm}$; $-26 \mathrm{M}-1,31-34 \mathrm{~cm} ;-28 \mathrm{M}-1,3-5 \mathrm{~cm} ;-30 \mathrm{M}-1,11-18 \mathrm{~cm} ;-35 \mathrm{M}-1,2-6 \mathrm{~cm}$; $-36 \mathrm{M}-1,106-110 \mathrm{~cm} ;-38 \mathrm{M}-1,13-17 \mathrm{~cm} ;-51 \mathrm{R}-3,107-110 \mathrm{~cm} ;-66 \mathrm{R}-1,33-37$ $\mathrm{cm}$, and $-4 \mathrm{R}-1,6-10 \mathrm{~cm}$.

This species is documented from the Hauterivian to the Paleogene (Pfender, 1936; Masse, 1976).

\section{Solenoporaceae}

\section{Genus Parachaetetes Deninger, 1906 Parachaetetes asvapatii Pia$$
\text { (Pl. 3, Figs. 4-5) }
$$

This form is represented by a nodular thallus consisting of cell rows, the transverse partitions of which are relatively thick (in comparison with the wall tube) and concave outward. The cells are about $0.04 \mathrm{~mm}$ wide, and the wall is a pale yellow color in thin section. These attributes conform to those from Elianella elegans Pfender and Basse, Cordilites cretosus Pocta, Petrophyton miyakoense Yabe, and Parachaetetes asvapatii Pia, all taxa now considered synonymous (Poignant, 1980; Moussavian, 1989). P. asvapatii is the valid name. Parachaetetes asvapatii was observed in Sample 144-878A-35M-1, 2-6 cm.

This taxon has a wide stratigraphic range, from the Albian to the Paleocene (Pfender and Basse, 1947; Poignant, 1980; Moussavian, 1989), but it has never been documented before the Albian. It is known from the Mediterranean regions to Nigeria and Madagascar, from the Caribbean to Brazil (Poignant, 1980; Granier et al., 1991a, 1991b), and from Japan (Yabe, 1912).

\section{Genus Solenopora Dybowski, 1877 Solenopora urgoniana Pfender} (Pl. 3, Figs. 6-7)

The irregular spacing of the elongated tubular cells, a characteristic feature of the genus, are well expressed here in the longitudinal and transverse sections from Sample 144-878A-78R-1,20-25 cm. The diameter of the tubes fluctuates from 0.03 to $0.04 \mathrm{~mm}$, a value conforming to that of Solenopora urgoniana described by Pfender (1930). This species is documented from the BarremianAlbian interval in the south of France (Pfender, 1930; Poignant, 1967; Masse, 1976) and Austria (Moussavian, 1989). 


\section{Algae of Uncertain Affinities}

Genus Pycnoporidium Yabe and Toyama, 1928

Pycnoporidium lobatum Yabe and Toyama (PI. 3, Fig. 8)

This genus has been ascribed to Solenoporaceae (Johnson, 1963; Tchuvashov et al., 1987), green algae (Elliott, 1963), and even to cyanophytes (Masse, 1976, 1979). The structure is close to Solenopora, with a tubular arrangement of the cells and inner partitions. However, the tubes are not packed enough to form a tissue; they are more or less embedded in a micritic matrix, a pattern that can be related to its filamentous rather than cellular organization (Elliott, 1969). Moreover, the tubes are mainly meandriform. The general organization of a specimen found in Sample 144-879A-2R-1, 89-94 cm, and the tube diameter $(0.04-0.05 \mathrm{~mm})$ conform to those of Pycnoporidium lobatum Yabe and Toyama.

This form shows a wide stratigraphic range, from the Jurassic to the Lower Cretaceous (Barattolo, 1990a).

\section{Genus Marinella Pfender, 1939 \\ Marinella lugeoni Pfender}

(Pl. 3, Figs. 9-10)

The systematic position of the genus within the calcareous algae has been debated. Pfender (1939) regarded Marinella as a cyanophyte, as did one of us (Masse, 1979). Other authors have ascribed it to green algae or to Solenoporaceae (see discussion in Barattolo and del Ré, 1985). This taxon is well characterized by the low, strong branching habit of its thallus with a thin filamentous structure. The diameter of the filaments is about $0.010 \mathrm{~mm}$ on average. Sections provided by Samples 144-879A-14R-1, 8-13 cm, and -2R-1 $132-138 \mathrm{~cm}$, conform to Marinella lugeoni Pfender. This species is close to Marinella yugoslavica Maslov, but it displays a limited number of ramifications, the length of which is also reduced, and it has a relatively smaller size (Barattolo and del Ré, 1985).

The specimens recorded here are found together with encrusting, microbial, pelletoidal micrites coating rudist fragments.

The stratigraphic range of Marinella lugeoni is from the Upper Jurassic to the Turonian. Its geographic distribution runs from Africa and Eurasia to the Americas (Barattolo and del Ré, 1985).

\section{CONCLUSIONS}

\section{Biostratigraphy}

\section{MIT Guyot (Site 878)}

The older calcareous algae occur since the base of the lower platform unit, but are present in few layers. The most important form is Solenopora urgoniana, which occurs in the basal $25 \mathrm{~cm}$ of carbonate Unit V (and not at the top of the volcanic breccia). This species is known to range from the Barremian to the Albian; then, age constraints for the basal carbonates are derived from calcareous plankton, which indicate an early Aptian age for the inception of carbonate deposition (see Erba et al., this volume). The remainder of the lower platform yielded only scattered Polystrata alba, which were not age diagnostic. Richer algal assemblages were recovered in the calcareous clast of the polymictic breccias (Unit IV). The species identified (Polystrata alba, Salpingoporella cf. muehlbergii, Salpingoporella cf. melitae, Montiella elitzae, Acroporella radoiciciae, and Similiclypeina somalica) are all of lower Aptian age. This indicates that the source of the bioclastic material is the lower carbonate platform, which was disrupted by the phreatomagmatic eruption. However, the associated benthic foraminifers within the matrix indicate that the deposition of the breccia occurred during the late Aptian (see Arnaud Vanneau, this volume). In Unit III we found Boueina sp., Polystrata alba, Parachaetetes asvapatii, and Triploporella aff. steinmannii, an assemblage strongly suggesting an Albian age, conforming to those provided by other chronostratigraphic indexes (Erba et al., this volume). At the topmost part of Unit II, the occurrence of Suppiluliumaella sp. and Cylindroporella $\mathrm{cf}$. barnesii also suggest an Albian age.

\section{Takuyo-Daisan Guyot (Site 879)}

Subunit IC and the basal part of Subunit IB provided Terquemella cf. antiqua, suggesting an Albian age. The presence in Subunit IC of a diagnostic late Aptian calcareous plankton (Erba et al., this volume) shows that Terquemella cf. antiqua already exists in the upper Aptian. On top of Subunit IA, the occurrence of Neomeris cretacea, Zittelina sp., Marinella lugeoni, and Pycnoporidium lobatum also supports, in that context, an Albian age, also assumed after analyzing other data (this volume).

\section{Paleoecology}

In the two sections studied, calcareous algal assemblages are dominated by dasyclads, the occurrence of which indicates very shallow warm waters (Elliott, 1984; Masse, 1988); nevertheless, red algae are locally common.

At Site 878, the taxonomic diversity is low in Units V and II, interpreted as mainly low-energy, restricted deposits (Premoli Silva, Haggerty, Rack, et al., 1993). Higher diversities are recorded in Unit IV and in the middle part of Unit III. The highest diversity is observed in the reworked clasts found in Unit IV, supporting the existence of a well-oxygenated, open-marine antecedent platform. Similar conditions are also postulated for the middle part of Unit III, concurring with previous interpretations. Dasyclad occurrences on top of Unit II are coupled with a relatively rich gastropod fauna in lagoonal settings.

At Site 879 , the highest taxonomic diversity is also observed in open-marine sediments (Subunit IA). Terquemella-rich deposits are essentially muddy, supporting low-energy and more or less restricted conditions.

\section{Paleobiogeography}

The discovery of the above-mentioned algal assemblages of Aptian-Albian age on Takuyo-Daisan and MIT guyots corroborates the location of these sites in the mesogean sensu Masse, 1992, Tethyan warm belt at that time. The two sites now situated at $34^{\circ} 10^{\prime} \mathrm{N}$ and $27^{\circ} 19^{\prime} \mathrm{N}$, respectively, were formerly at about $10^{\circ}$ and $15^{\circ} \mathrm{S}$ (Winterer, 1991). The mesogean meaning of these assemblages can also be derived from the other warm shallow-water-associated organisms.

The species identified are identical or very close to those of the corresponding time intervals in the Mediterranean regions.

The genera recorded here (Salpingoporella, Marinella, Pycnoporidium, Parachaetetes, Solenopora, and Polystrata, formerly listed as Ethelia), were mentioned from the Daiichi-Kashima and nearby guyots from the Japanese group (Konishi, 1989). The presence of Acroporella radoiciciae, Cylindroporella $\mathrm{cf}$. barnesii, Montiella elitzae, Neomeris cretacea, Salpingoporella cf. muehlbergii, Salpingoporella cf. melitae, Similiclypeina somalica, Suppiluliumaella sp., Terquemella cf. antiqua, Triploporella aff. steinmannii, Zittelina sp., and Boueina sp. is reported for the first time in the Pacific. Of particular importance is the presence of typical or closely related forms from the Mediterranean area: Acroporella radoiciciae, Montiella elitzae, Salpingoporella melitae, and Salpingoporella muehlbergii, associated with some Caribbean elements (Cylindroporella barnesii and Triploporella steinmannii) as well as with cosmopolitan Tethyan ones (such as Similiclypeina somalica and Neomeris cretacea). These occurrences show that the northwest Pacific was widely connected with the rest of the Tethys during the Aptian-Albian. This result differs from those concerning rudists from the Mid-Pacific Mountains (Swinburne and Masse, in press), which contain several endemic taxa that suggest a possible Pacific province or endemic center.

\section{ACKNOWLEDGMENTS}

We would like to thank F. Barattolo, M.A. Conrad, and I. Premoli Silva for reviewing the manuscript and for their helpful comments. 
Technical help was provided by G. Haufeurt and M. Lécorché from the University of Provence.

\section{REFERENCES ${ }^{*}$}

Bakalova, D., 1971. Nouvelles espèces de Dasycladaceae dans les sédiments urgoniens du Prébalkan central. Izv. Geol. Inst., Bulg. Akad. Nauk., Ser. Paleontol., 20:123-128.

Barattolo, F., 1980. Su alcune nuove Triploporella (alghe verdi, Dasycladacea) del Cretacico inferiore dell'Appennino campano. Boll. Soc. Nat. Napoli, 89.

_ 1981. Osservazioni su Triploporella fraasi Steinmann 1880 (alghe verdi, Dasicladali). Att. Academ. Pontian., n.s. 30:1-40.

, 1982a. Osservazioni su Triploporella praturlonii n.sp. (alghe verdi, Dasicladali) del Cretacico inferiore dell'Appennino centrale. Geol. Rom., 21:825-847.

, 1982b. Osservazioni su Triploporella steinmannii n.sp. (alghe verdi, Dasicladali) del Cretacico del Mexico. Boll. Soc. Nat Napoli, 91:1-35.

_ 1983. Osservazioni su Suppiluliumaella schroederi n.sp. (alghe verdi, Dasicladali) del Cenomaniano del Matese (Appennino meridionale, Italia). Boll. Soc. Nat. Napoli, 92:1-27.

, 1985. New data on tribe Bornetelleae (Chlorophyta, Dasycladales). Boll. Soc. Nat. Napoli, 93:1-59.

, 1990a. Mesozoic and Cenozoic marine benthic calcareous algae with particlar regard to Mesozoic dasycladaceans. In Riding, R. (Ed.)., Calcareous Algae and Stromatolites: Berlin (Springer-Verlag), 504-540,

- 1990b. Remarks on Neomeris cretacea Steinmann (Chlorophyta, Dasycladales) from the Cretaceous of Orizaba (type-locality), Mexico. Boll. Soc. Paleont. Ital., 29:207-218.

Barattolo, F., and del Ré, M.C., 1985. Alghe rosse Solenoporae del Cenomaniano dei dintorni di Caserta (Appennino meridionale, Italie). Boll. Soc. Nat. Napoli, 93:1-53.

Bassoullet, J.P., Bernier, P., Conrad, M.A., Deloffre, R., and Jaffrezo, M., 1978. Les Algues Dasycladales du Jurassique et du Crétacé; révision critique. Geobios, Mem. Spec,, 2.

Bucur, I., 1993. Some new or poorly known calcareous algae (Dasycladales, Gymnocodiaceae) in the lower Cretaceous deposits from the Resita-Moldova Nova zone (Southern Carpathians, Romania). Rev. Esp. Micropaleontol., 25:93-126.

Conrad, M.A., 1982. Comments on Korkyrella and other new Dasycladaceae. Rev. Paleobiol., 1:1-4.

Conrad, M.A., and Masse, J.P., 1989. Les Algues calcaires des formations carbonatées de l'Hauterivien-Barrémien pro-parte du Jura vaudois et neuchâtelois (Suisse). Mem. Soc. Neuchatel Sci. Nat., 11:277-290.

Conrad, M.A., Peybernès, B., and Masse, J.P., 1983. Clypeina somalica n. sp., dasycladale nouvelle du Crétacé inférieur de la plaque africaine (Rep. de Somalie, Italie méridionale). Ann. Soc. Geol. Nord, 103:93-96.

Denizot, M., 1968. Les algues Floridées encroûtantes (à l'exclusion des Corallinacées). Imp. pers. de l'auteur, Paris.

Dragastan, O., 1967. Algues calcaires du Jurassique supérieur et du Crétacé inférieur des Monts Apuseni. St. si Cerc. Geol. Geofiz. Geogr., Ser. Geol., 12:441-454.

— 1969. Algues calcaires du Jurassique supérieur et du Crétacé inférieur de Roumanie. Rev. Micropaleontol., 1:53-62.

, 1971. New algae in the Upper Jurassic and Lower Cretaceous in the Bicaz Valley, East Carpathians (Romania). Rev. Esp. Micropaleontol., 3:155-192.

$\longrightarrow, 1978$. Microfaciès de la série calcaire, Crétacé inférieur d'Aliman (Dobrogea du sud). Dari S. Sedint., Stratigr., 64:107-136.

, 1989. Calcareous algae (new and revised), microproblematical and foraminiferida of Jurassic-Lower Cretaceous deposits from the Carpathian area. Rev. Esp. Micropaleontol., 21:5-65.

Dragastan, O., Bucur, I., and Demeter, I., 1977. Nouvelles données sur la biostratigraphie des dépôts du Barrémien-Albien de la partie centrale orientale de la zone de Resita-Moldova Nova (Banat), acquises par le forage de référence de Sopotul Nou. Dari S. Sedint., Stratigr., 64:17-36.

Elliott, G.F., 1963. A liassic Pycnoporidium (Calcareous algae). Eclogae Geol. Helv, 56:179-181.

-Abbreviations for names of organizations and publications in ODP reference lists follow the style given in Chemical Abstracts Service Source Index (published by American Chemical Society).
, 1968. Three new tethyan Dasycladaceae (Calcareous algae). Paleontology, 11:491-497.

1984. Climatic tolerance in some aragonitic green algae of the post-Palaeozoic. Palaeogeogr., Palaeoclimatol., Palaeoecol., 48:163169.

Genot, P., 1987. Les Chlorophycées calcaires du Paléogène d'Europe Nordoccidentale (Bassin de Paris, Bretagne, Cotentin, Bassin de Mons) [Thèse Doctorat]. Nantes.

Granier, B., 1986. Algues Chlorophycées du Jurassique terminal et du Crétacé inférieur en Alicante. Mediterranea, Alicante, 5:5-96.

, 1990. Révision de Cylindroporella benizarensis Fourcade et al., ex. Jaffrezo in Bassoullet et al., 1978. Rev. Esp. Micropaleontol., 22:305312 .

, 1992. Les algues et foraminifères benthiques du Jurassique supérieur et du Crétacé inférieur du Sénégal. J. Afr. Earth Sci., 14:239-253.

Granier, B., Berthou, P.Y., and Fourcade, E., 1991a. The Dasycladacean algae from the Cretaceous of the New World. Trans. 2nd Geol. Conf. Geol. Soc., Trinidad and Tobago, Port of Spain, 178-183.

Granier, B., Berthou, P.Y., and Poignant, A.F., 1991b. Constructions biosédimentaires laminées, Lithothamnium et Parachaetetes de la formation Riachuelo (Albien) du bassin de Sergipe (Nord-est du Brésil). Geociencias, 10:169-181.

Granier, B., and Deloffre, R., 1993. Inventaire critique des algues dasycladales fossiles. 2è partie: les algues dasycladales du Jurassique et du Crétacé. Rev. Paleobiol., 12:19-65.

Grötsch, J., 1991. Die evolution von karbonatplattformen des offenen Ozeans in der mittleren Kreide (NW-Jugoslawien, NW-Pazifik, NW-Griechenland): Moeglichkeiten zur Rekonstruktion von Meeresspiegelaenderungen verschiedener Groessenordnung [Doctoral dissert.]. Friedrich Alexander Univ. Erlangen-Nuernberg, Federal Republic of Germany.

Grötsch, J., and Flügel, E., 1992. Facies of sunken Early Cretaceous atoll reefs and their capping late Albian drowning succession (northwestern Pacific). Facies, 27:153-174.

Hamilton, E.L., 1956. Sunken islands of the Mid-Pacific Mountains. Mem.Geol. Soc. Am., 64.

Johnson, H.J., 1954. Cretaceous Dasycladaceae from the Gillespie county, Texas. J. Paleontol., 28:787-790.

, 1968a. Lower Cretaceous algae from Texas. Prof. Contrib.-Colo. Sch. Mines, 4.

, 1968b. Lower Cretaceous algae from the Blake Escarpment, Atlantic Ocean, and from Israel. Pt. 1, Lower Cretaceous algae from the Blake Escarpment, Atlantic Ocean. Colo. Sch. Mines Prof. Contrib., 5:1-27. $58: 211$.

Konishi, K., 1989. Limestone of the Daiichi Kashima Seamount and the gate of a subducting guyot: fact and speculation from the Kaiko "Nautile" dives. Tectonophysics, 160:249-265.

Kuss, J., and Conrad, M.A., 1991. Calcareous algae from Cretaceous carbonates of Egypt, Sinai and southern Jordan. J. Paleontol., 65:869-882.

Luperto-Sinni, E., and Masse, J.P., 1984. Données nouvelles sur la micropaléontologie et la stratigraphie de la partie basale du "Calcare di Bari" (Crétacé inférieur) dans la région des Murges (Italie méridionale). Riv. Ital. Paleontol. Stratigr., 90:331-374.

Masse, J.-P., 1976. Les calcaires urgoniens de Provence. Stratigraphie, paléontologie, les environnements et leur évolution. [Thèse Doctorat Etat]. Univ. Aix-Marseille II.

, 1979. Schizophytoïdes du Crétacé inférieur. Caractéristiques et signification écologique. Bull. Cent. Rech. Explor-Prod. Elf-Aquitaine, 3:685-703.

_ 1988. L'étagement bionomique des milieux benthiques néritiques actuels: signification bathymétrique et implications paleobathymétriques. Geol. Mediterr., 15:91-102.

, 1992. The Lower Cretaceous Mesogean benthic ecosystems: palaeoecologic aspects and palaeobiogeographic implications. Palaeogeogr., Palaeoclimatol., Palaeoecol., 91:331-345.

Masse, J.P., Arias, C., and Vilas, L., 1992. Stratigraphy and biozonation of a reference Aptian-Albian p.p. Tethyan carbonate platform succession: the Sierra del Carche series (oriental Prebetic zone-Murcia, Spain). In Kollmann, H.A., and Zappe, H. (Eds.), New Aspects on Tethyan Cretaceous Fossil Assemblages. Osterreich Akad. Wissen. Schrift. Erdw. Komm., 9:201-222.

- 1993. Zittelina hispanica et Suppiluliumaella minuta, Dasycladales nouvelles de l'Hauterivien du Sud-Est de l'Espagne. Rev. Micropaleontol., 36:293-300. 
Moussavian, I., 1989. Über die systematiche stellung und die bestimmungs kriterien der Solenoporaceen (Rhodophyceae). Cour. Forschungsinst. Senckenberg., 109:51-91.

Munier-Chalmas, E.P., 1877. Observations sur les algues calcaires appartenant au groupe des Siphonées verticillées (Dasycladacées Harv.) et confondues avec les Foraminifères. C. R. Acad. Sci., 85:814-817.

Pascal, A., 1986. Stratigraphic and sedimentary interpretation of Cretaceous limestones (Daiichi-Kashima Seamount, Kaiko Cruise 1985, Legs 2 and 3). Abst. Internat. Kaiko Conf. on Subduction Zones, 100-101.

Pfender, J., 1930. Sur la présence d'une Solenopore dans l'Urgonien du Sud-Est de la France: Solenopora urgoniana n. sp. Bull. Soc. Geol. Fr, 4:101-105.

, 1936. Sur un organisme constructeur des calcaires crétacés et Nummulitiques: Pseudolithothamnium album nov. gen. nov. sp. Bull. Soc. Geol. Fr., 5:303-308.

, 1939. Sur un calcaire phytogene du Lias inférieur d'Espagne et l'extension de ce faciès en quelques autres régions. Bull. Soc. Vaudoise Sci. Nat., 60:213-228.

Pfender, J., and Basse, E., 1947. Elianella nov. gen. elegans nov. sp. organisme constructeur de calcaires typiquement développé dans le Paléocène du SW malgache. Bull. Soc. Geol. Fr., 5:275-278.

Pia, J., 1936. Calcareous green algae from the Upper Cretaceous of Tripoli (North Africa). J. Paleontol., 10:3-13.

Poignant, A., 1967. Les algues du Crétacé inférieur de Tercis (Landes). C. $R$. Acad. Sci. Ser. D, 264:1145-1147.

Poignant, A.F., 1980. Réflexions sur le genre Elianella Pfender et Basse (Algue rouge). 8ème R.A.S.T., Marseille. Soc. Geol. Fr, 286.

Praturlon, A., 1964. Calcareous algae from Jurassic-Cretaceous limestones of Central Apennines (Southern Latium-Abruzzi). Geol. Rom., 3:171-202.

Praturlon, A., and Radoicic, R., 1974. Emendation of Acroporella (Dasycladaceae). Geol. Rom., 13:17-20.

Premoli Silva, I., Haggerty, J., Rack, F., et al., 1993. Proc. ODP, Init. Repts., 144: College Station, TX (Ocean Drilling Program).

Prestat, B., 1977. Marqueurs micropaléontologiques du Jurassique et du Crétacé de Somalie centrale. Act. VI Colloq. Afr. Micropaleontol., Tunis 1974. Ann. Mines Geol. (Tunis), 28:273-309.

Radoicic, R., 1965. Salpingoporella melitae spec. nov. des sédiments Crétacés inférieurs des Dinarides externes. Zapisnici Srp. Geol. Drus., 27:120-127.
1969. A new lower Cretaceous Dasycladacea, Clypeina pejovici, and note on some Clypeinae. Geol. Rom., 8:71-84.

, 1972. A new Neocomian dasycladacea Suppiluliumaella gocanini from the environs of Orahovac (Mirdita zone). Bull. Sci., Sect. A (Zagreb), 17:364-365.

, 1980. Contribution to the reconsideration of a group of Cylindroporelliform dasyclads. Bull.-Acad. Serbe Sci. Arts, 20:109-115.

Saint-Marc, P., 1970. Contribution à la connaissance du Crétacé basal au Liban. Rev. Micropaleontol., 4:224-233.

Sokac, B., 1990. Cylindroporella bradarici n. sp. (calcareous algae, Dasycladales) from the Albian of the Dinaric karst area. Geol. Vjesn., 43:1-6.

Sokac, B., and Nikler, L., 1973. Cretaceous algae from the lower Cretaceous of the environs of Niksic, Crna Gora (Montenegro). Paleontol. Jugosl,, 13:57.

Swinburne, N., and Masse, J.P., in press. Early Cretaceous rudist fauna of Allison and Resolution guyots, Mid-Pacific Mountains. In Winterer, E.L., Sager, W.W., Firth, J.V., and Sinton, J.M. (Eds.), Proc. ODP, Sci. Results, 143: College Station, TX (Ocean Drilling Program).

Tchuvashov, B.I., Poutsinina, V.A., Tchuiski, V.P., Tchaykin, I.M., Bertchenko, A.A., Saptovckaya, V.D., and Tchitchova, D.I., 1987. Iskopemie Isvestkovye Vodoroslie: Novosibirsk (Nauka).

Winterer, E.L., 1991. The Tethyan Pacific during Late Jurassic and Cretaceous times, Palaeogeogr., Palaeoclimatol., Palaeoecol., 87:253-265.

Winterer, E.L., Natland, J.H., van Waasbergen, R.J., Duncan, R.A., McNutt, M.K., Wolfe, C.J., Premoli Silva, I., Sager, W.W., and Sliter, W.V., 1993. Cretaceous guyots in the Northwest Pacific: an overview of their geology and geophysics. In Pringle, M.S., Sager, W.W., Sliter, W.V., and Stein, S. (Eds.), The Mesozoic Pacific: Geology, Tectonics, and Volcanism. Geophys. Monogr., Am. Geophys. Union, 77:307-334.

Yabe, H., 1912. Uber einige Gesteinsbildende kalkalgan von Japan und China. Sci. Rep. Tohoku Univ., Ser. 2, 1:8.

Yabe, H., and Toyama, S., 1928. On some rock forming algae from the younger Mesozoic of Japan. Sci. Rep. Tohoku Imp. Univ., 12:141-152.

Date of initial receipt: 31 January 1994

Date of acceptance: 26 June 1994

Ms 144SR-073 


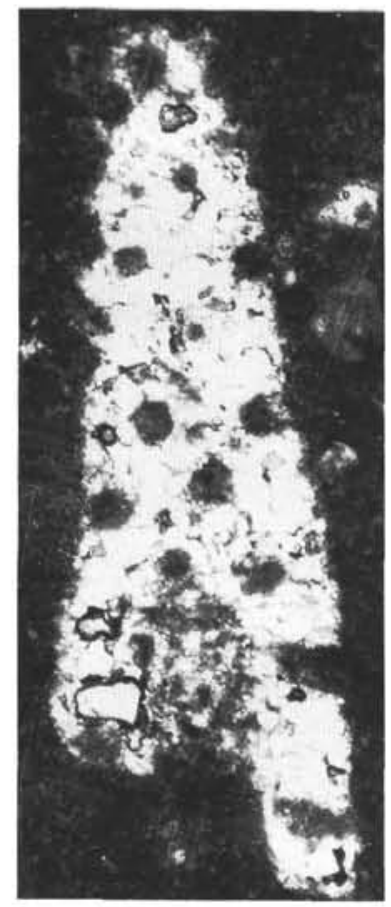

1

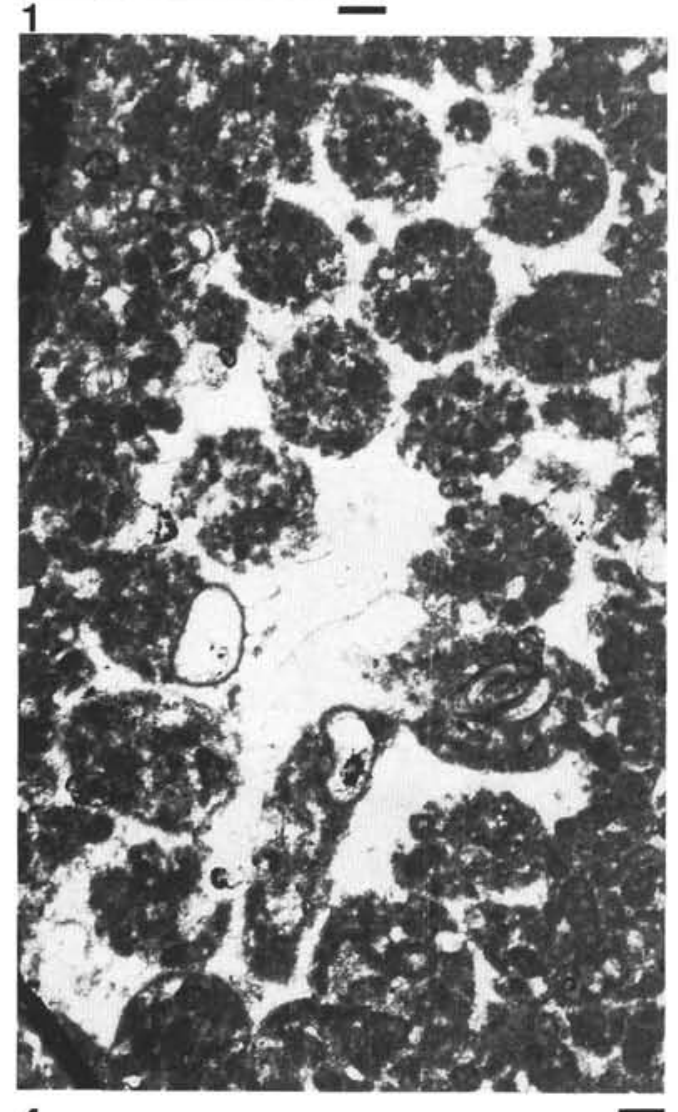

4
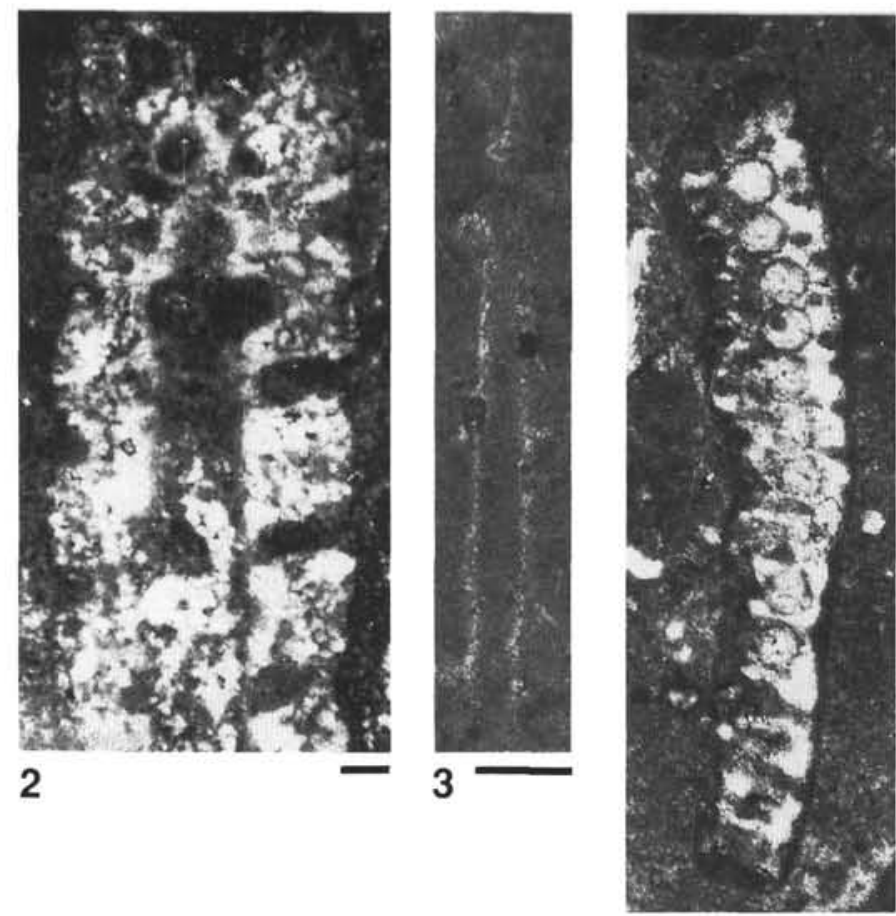

6
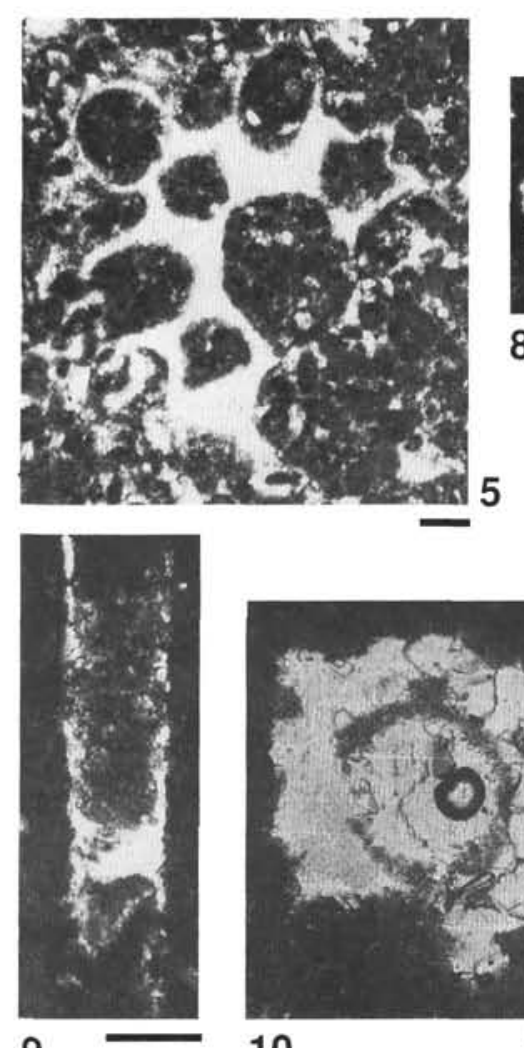

9

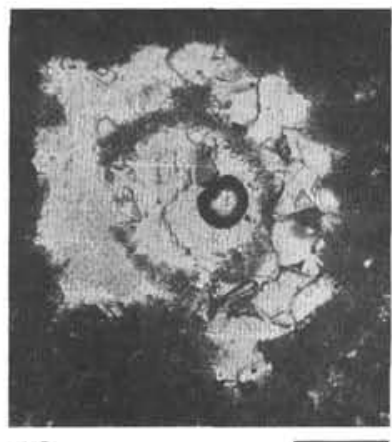

10

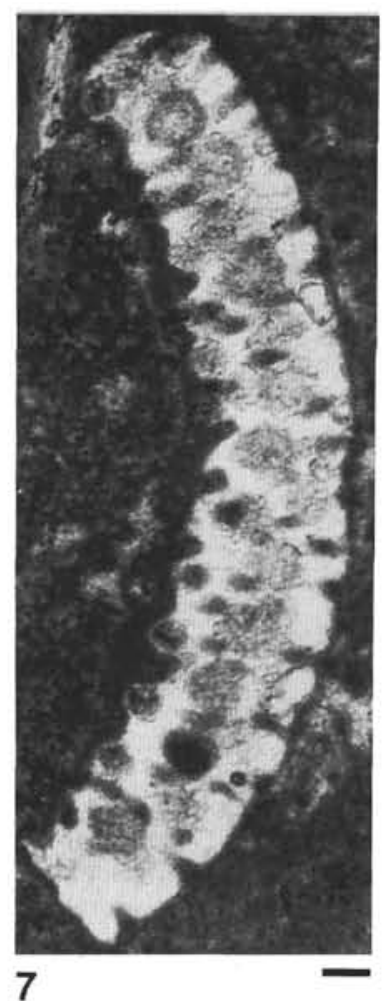

7

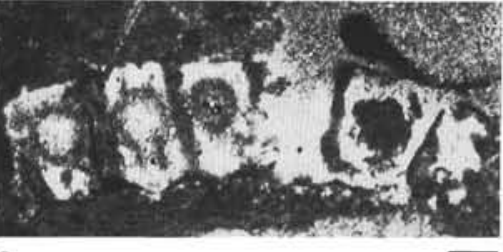

8

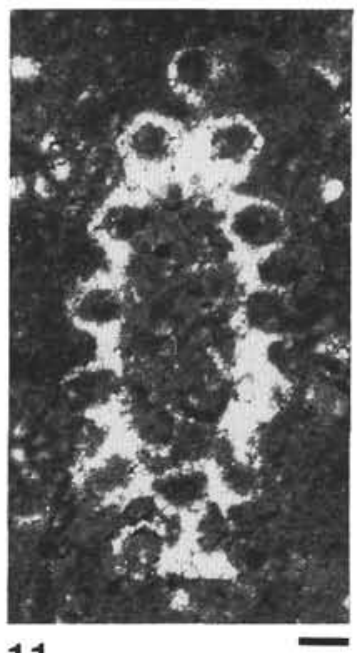

11

Plate 1. 1. Acroporella radoiciciae, Sample 144-878A-45M-3,123-125 cm, longitudinal oblique section. 2. Acroporella radoiciciae, Sample 144-878A$46 \mathrm{M}-3,123-125 \mathrm{~cm}$, longitudinal section. 3. Cylindroporella $\mathrm{cf}$. barnesii, Sample 144-878A-2R-1, 3-4 cm, longitudinal section. 4. Montiella elitzae, Sample 144-878A-51R-2, 5-9 cm, longitudinal oblique section. 5. Montiella elitzae, same sample, subtangential section. 6. Neomeris cretacea, Sample 144-879A-2R-1, 132-138 cm, oblique section. 7. Neomeris cretacea, Sample 144-879A-2R-1,89-84 cm. 8. Neomeris cretacea, Sample 144-879A-2R-1, 132-138 cm. 9. Salpingoporella cf. muehlbergii, Sample 144-878A-61R-2, 75-78 cm, longitudinal section. 10. Salpingoporella cf. melitae, Sample 144-878A-55R-3, 46-49 cm, transverse section. 11. Similiclypeina somalica, Sample 144-878A-45M-3, 123-125 cm, longitudinal section. Scale bar: white $=0.1 \mathrm{~mm}$, black $=0.2 \mathrm{~mm}$. 

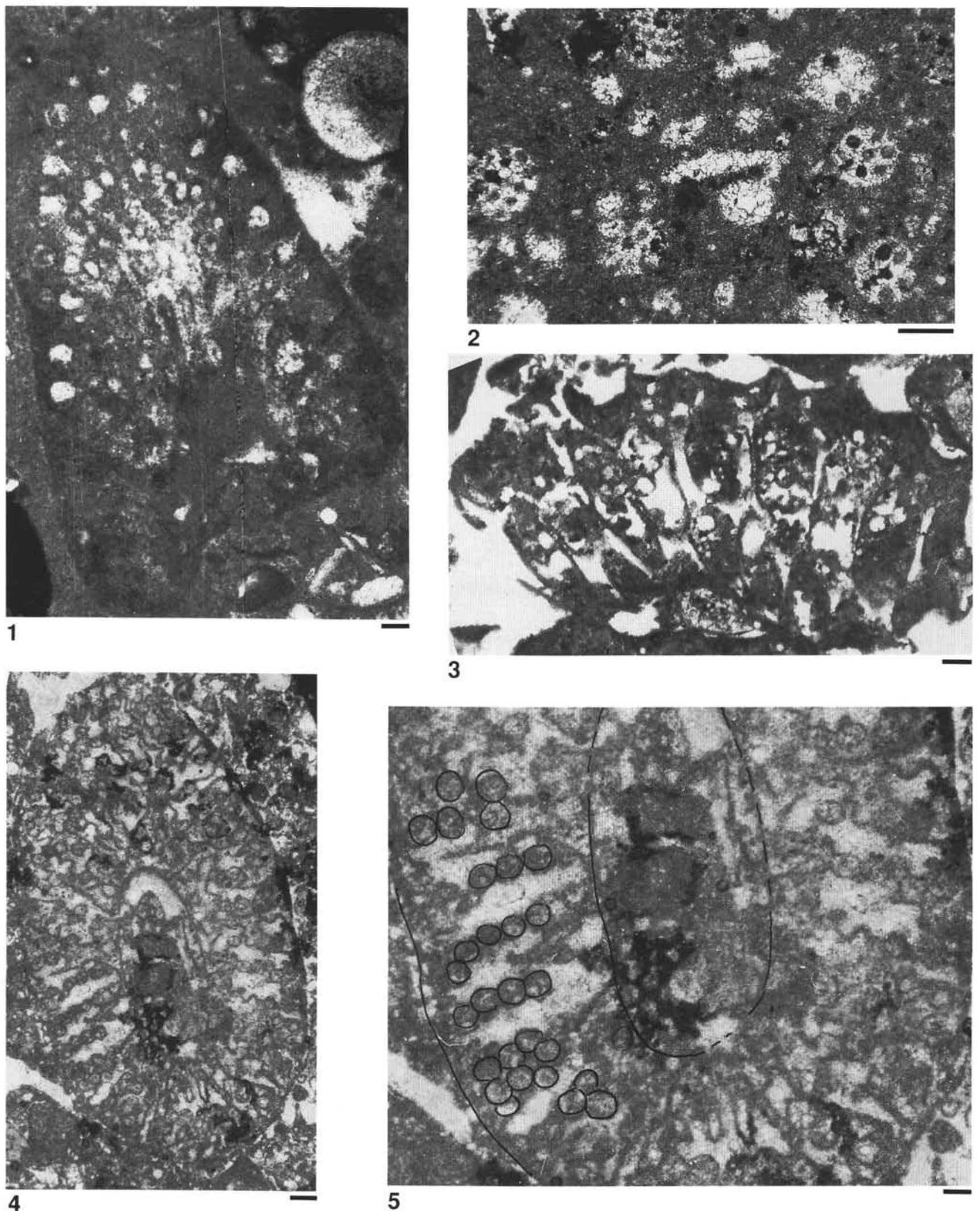

Plate 2. 1. Suppiluliumaella sp., Sample 144-879A-2R-1,132-138 cm, longitudinal oblique section. 2. Terquemella cf. antiqua, Sample 144-879A-16R-1, $95-99 \mathrm{~cm}$, randomly cut sections. 3. Triploporella aff. steinmannii, Sample $144-878 \mathrm{~A}-37 \mathrm{M}-2,32-35 \mathrm{~cm}$, oblique section of a thallus fragment. 4. Zittelina sp., Sample 144-879A-2R-1, 0-4 cm, longitudinal section. 5. Zittelina sp., same sample, close-up showing the shape and arrangement of the cyst containers. 


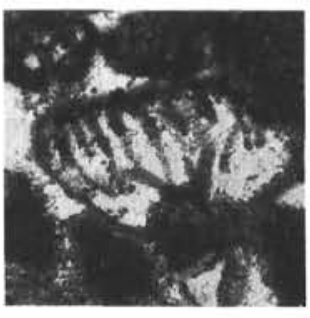

1

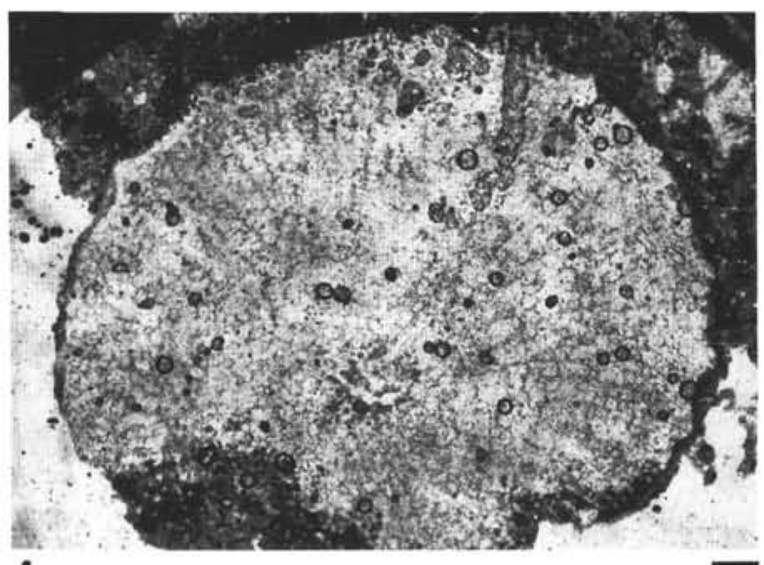

4

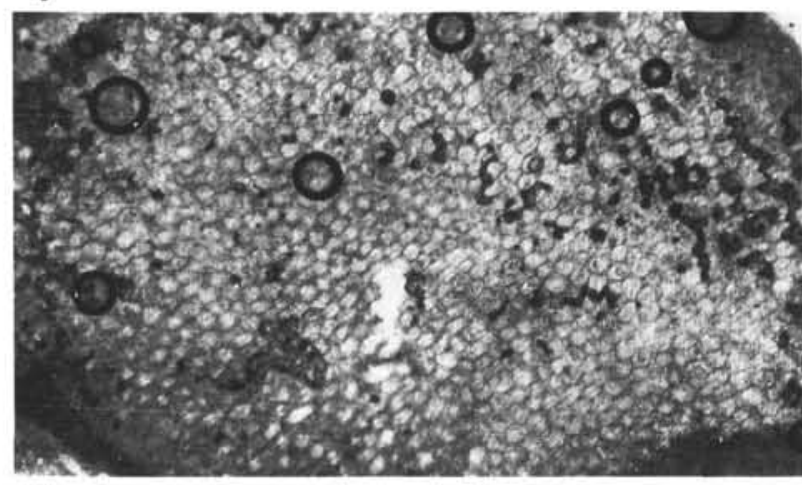

6

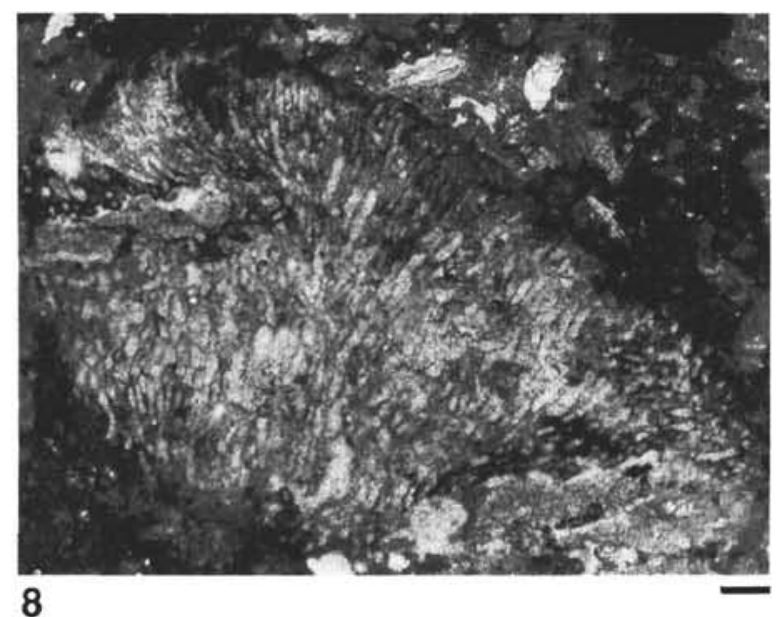

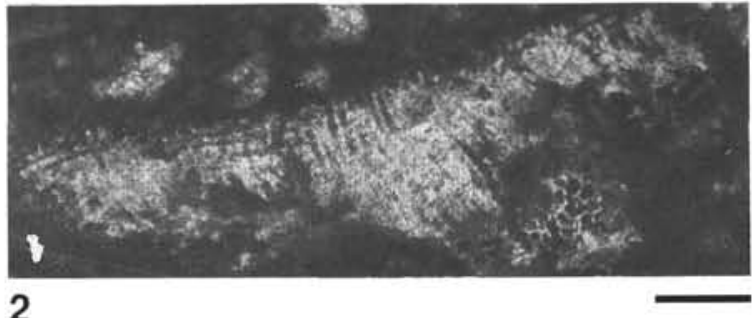

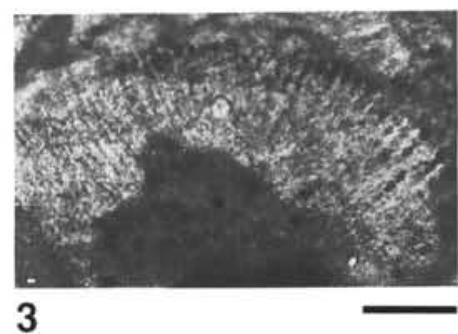

3

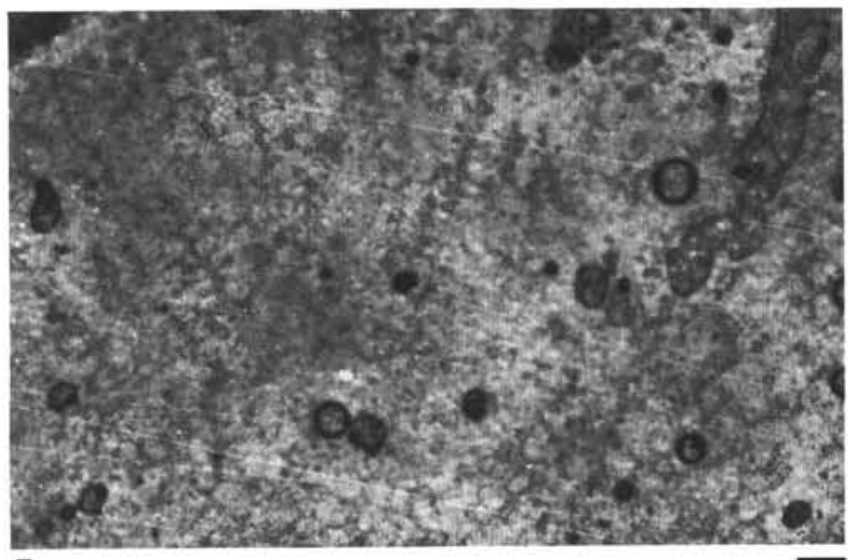

5

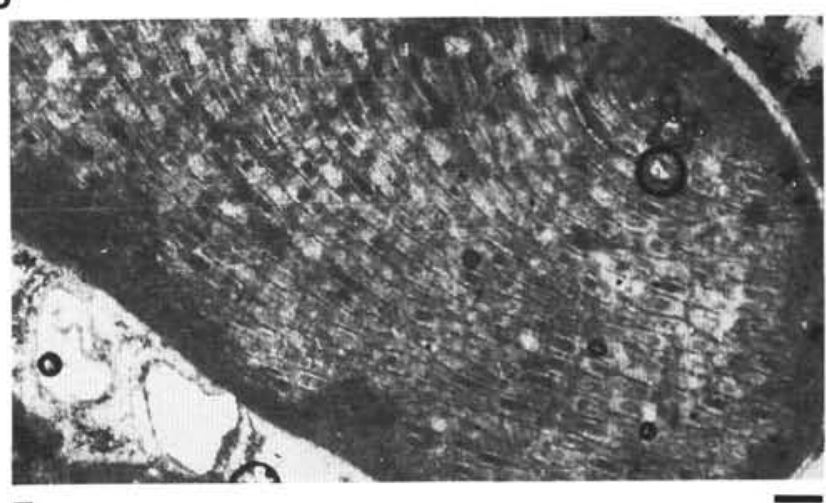

7
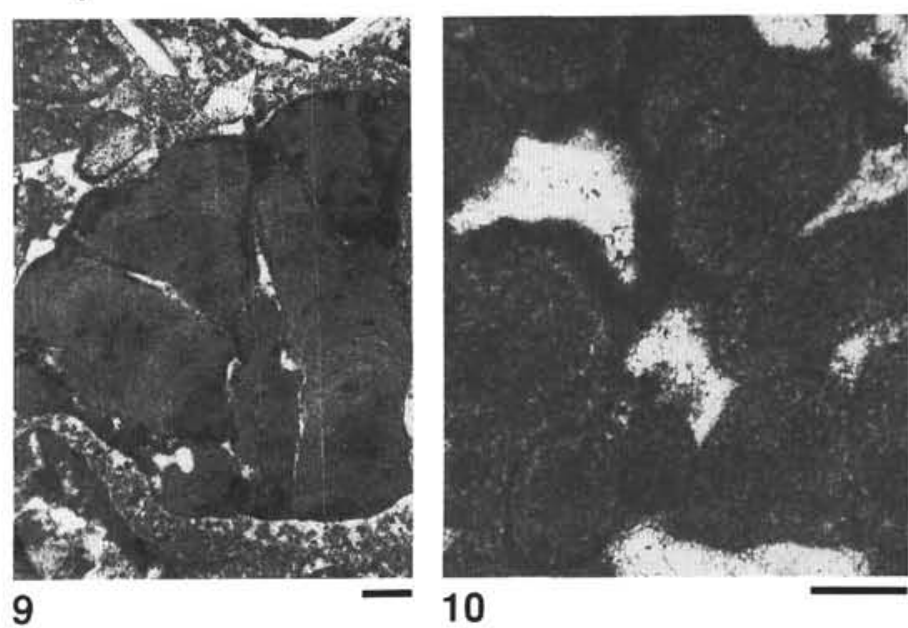

Plate 3. 1. Boueina sp., Sample 144-878A-30M-1, 29-31 cm, section of the cortical part. 2. Polystrata alba, Sample 144-878A-68R-1, 11-16 cm, longitudinal section. 3. Polystrata alba, Sample 144-878A-45M-2, $89-93 \mathrm{~cm}$. 4. Parachaetetes asvapatii, Sample 144-878A-35M-1, 2-6 cm, cross section of the thallus. 5. Parachaetetes asvapatii, Sample 144-878A-35M-1, close-up showing the cell rows with concave septa. 6. Solenopora urgoniana, Sample 144-878A-35M-1, 2-6 cm, transverse section. 7. Solenopora urgoniana, Sample 144-878A-35M-1, 2-6 cm, longitudinal section. 8. Pycnoporidium lobatum, Sample 144-879A-2R-1, 89-94 cm, cross section. 9. Marinella lugeoni, Sample 144-879A-2R-1, 132-138 cm, longitudinal section. 10 . Marinella lugeoni, Sample 144-879A-14R-1, 8-13 cm, transverse section. 